\title{
An Evaluation of Hormone Levels in Behçet's Disease
}

\author{
Behçet Hastalığında Hormon Düzeylerinin Değerlendirilmesi
}

\author{
Sema KARAKUŞ, ${ }^{\text {Aslı NAR, }}{ }^{2}$ Selami Koçak TOPRAK, ${ }^{1}$ Figen ATALAY, ${ }^{1}$ Osman İlhami ÖZCEBE ${ }^{3}$ \\ ${ }^{1}$ Department of Hematology, Başkent University School of Medicine, Ankara, Turkey; \\ ${ }^{2}$ Department of Endocrinology and Metabolism, Başkent University School of Medicine, Ankara, Turkey; \\ ${ }^{3}$ Department of Internal Medicine, Division of Hematology, Hacettepe University School of Medicine, Ankara, Turkey
}

\begin{abstract}
Objectives: This study aims to evaluate the basal serum levels of the hypophysial, thyroidal, adrenal, and gonadal hormones and the disease activity in patients with Behçet's disease (BD).
\end{abstract}

Patients and methods: Forty-three patients (22 males, 21 females; mean age 34 years; range 21 to 46 years) were divided into the following four groups according to the disease activity and presence of ocular involvement: Active BD $(n=27)$, inactive BD $(n=16)$, those with ocular involvement $(n=14)$, and those without ocular involvement $(n=29)$. A group of 40 (18 male, 22 female) healthy subjects matched according to age and gender were used as the negative control group. A positive control group (two males and 14 females) consisted of 16 patients with systemic lupus erythematosus. Triiodothyronin, thyroxin, the thyroid-stimulating hormone, the folliclestimulating hormone, the luteinizing hormone, the growth hormone $(\mathrm{GH})$, dihydroepiandrosterone sulphate (DHEAS), estradiol, testosterone, basal cortisol, prolactin (PRL), and the adrenocorticotropic hormone were evaluated in all subjects.

Results: No clinically significant differences were found between the BD groups and negative control group in terms of the basal serum levels of the hypophysial, thyroidal, adrenal, and gonadal hormones. When the hormonal values were evaluated with regard to disease activity and ocular involvement, the BD patients with ocular involvement showed significantly higher PRL and $\mathrm{GH}$ values in both genders and significantly lower DHEAS levels in female patients.

Conclusion: Despite being a vasculitis-related disease, we can conclude that BD has no major influence on the endocrine system. Also, further, large-scale studies are needed to evaluate the correlations between $\mathrm{PRL}, \mathrm{GH}$, and DHEAS values and ocular involvement.

Key words: Behçet's disease; disease activity; hormone levels; ocular involvement; vasculitis.
Amaç: Bu çalışmada, Behçet hastalığında $(\mathrm{BH})$ hipofizyal, tiroidal, adrenal ve gonadal hormonların bazal serum düzeyleri ile bu hormonların hastalık aktivitesi arasındaki ilişkileri değerlendirildi.

Hastalar ve yöntemler: Kırk üç hasta (22 erkek, 21 kadın; ort. yaş 34 yıl; dağılım 21-46 yıl), hastalık aktivitesi ve oküler tutulum varlığına göre dört gruba ayrılarak değerlendirildi: Aktif $\mathrm{BH}(\mathrm{n}=27)$, inaktif $\mathrm{BH}(\mathrm{n}=16)$; oküler tutulum $(n=14)$ ve oküler tutulum olmayanlar $(n=29)$. Negatif kontrol grubu olarak benzer yaş ve cinsiyette 40 sağlıklı birey (18 erkek, 22 kadın) değerlendirmeye alındı. Pozitif kontrol grubuna ise 16 (2 erkek, 14 kadın) sistemik lupus eritematozus hastası dahil edildi. Çalışmaya alınan tüm bireylerde triiyodotironin, tiroksin, tiroid stimüle edici hormon, follikül stimüle edici hormon, lüteinize edici hormon, büyüme hormonu $(\mathrm{GH})$, dihidroepiandrosteron sülfat (DHEAS), östradiol, testosteron, bazal kortizol, prolaktin (PRL) ve adrenokortikotropik hormon düzeyleri değerlendirildi.

Bulgular: Negatif kontrol grubu ile BH grupları arasında, hipofizyal, tiroidal, adrenal ve gonadal hormonların bazal serum düzeylerine göre klinik bulgularda herhangi bir anlamlı değişiklik saptanmadı. Hormon düzeyleri ile hastalık aktivitesi ve oküler tutulum ilişkisine bakıldığında ise, oküler tutulumu olan her iki cinsiyetteki BH hastalarında PRL ve GH değerlerinin anlamlı yüksek, kadın hastalarda ise DHEAS seviyelerinin anlamlı düşük olduğu bulundu.

Sonuç: Vaskülitik bir hastalık olmasına karşın BH'nin endokrinolojik sisteme majör bir etkisi olmadığı söylenebilir. Bununla birlikte, PRL, GH ve DHEAS düzeyleri ile oküler tutulumu olan $\mathrm{BH}$ arasında saptanmış olan ilişkinin irdelenmesi için geniş ölçekli çalışmalara gereksinim vardır.

Anahtar sözcükler: Behçet hastalığı; hastalık aktivitesi; hormon düzeyleri; oküler tutulum; vaskülit.

Received: January 27, 2012 Accepted: April 28, 2012

Correspondence: Selami Koçak Toprak, M.D. Başkent Üniversitesi Tıp Fakültesi, İç Hastalıkları Anabilim Dalı, Hematoloji Bilim Dalı, 06490 Bahçelievler, Ankara, Turkey. Tel: +90 312 - 2122912 e-mail: sktoprak@yahoo.com

(02012 Turkish League Against Rheumatism. All rights reserved. 
Besides its classification as a neutrophilic dermatosis, Behçet's disease (BD) is also a chronic, relapsing multisystem inflammatory disorder that causes orogenital ulcerations, skin lesions such as palpable purpura, infiltrative erythema, and papulopustular lesions, intraocular inflammation, thromboembolism, and, less commonly, arthritic, gastrointestinal and neurologic manifestations. ${ }^{[1]}$ The disease presents a tendency toward thrombosis, and the prevalence of venous or arterial thrombosis in $\mathrm{BD}$ reaches $40 \%$ in some series. The etiology of BD still remains to be elucidated with infectious agents, geneticfactors, and immune mechanisms having been implicated. ${ }^{[2,3]}$ Genetic studies show an association between $\mathrm{BD}$ and the human leukocyte antigen B51. Interactions between the neuroendocrine, immune, and hematologic system play an important role in maintaining and restoring homeostasis. Abnormal serum prolactin levels are related to many immunohematologic diseases, including $\mathrm{BD}^{[4,5]}$ In addition, Colak et al. ${ }^{[6]}$ suggested that the hypothalamo-pituitary-adrenal axis is partially suppressed in BD. Based on this information, it seems likely that autoimmune diseases affecting hormonal status may also play a role in BD pathogenesis. Also, $\mathrm{BD}$ as a type of vasculitis may be expected to affect the endocrine organs.

The purpose of this study was to determine the basal serum levels of the hypophysial, thyroidal, adrenal, and gonadal hormones in patients with $\mathrm{BD}$ and evaluate the correlation between $\mathrm{BD}$ and disease activity.

\section{PATIENTS AND METHODS}

In this cross-sectional study, 43 patients $(22$ males and 21 females; mean age 34 years; range 21 to 46 years) who fulfilled the classification criteria of the International Study Group for Behçet's Disease (1990) and were followed up as outpatients in our department were included. ${ }^{[7]}$ The patients had been previously or newly diagnosed with $\mathrm{BD}$. To verify the clinical diagnosis of $\mathrm{BD}$, two or more investigators reviewed the patients' histories, medical records along with the pathergy and laboratory test results. All patients were also evaluated by the Ophthalmology, Dermatology, and Neurology departments. The study protocol was approved by the institutional ethics committee, and written and signed informed consent was provided by all of the participants.
The patients with BD were subdivided into the following four groups according to disease activity on the assumption that the presence and localization of the vasculitis may alter hormone levels: active $\mathrm{BD}$ (group 1, $\mathrm{n}=27$ ), inactive BD (group 2, $\mathrm{n}=16$ ); those with ocular involvement (group 3, $\mathrm{n}=14$ ), and those without ocular involvement (group $4, \mathrm{n}=29$ ). At the time of clinical assessment, patients were included in the active group if they had at least one of the following clinical and serological findings: thrombophlebitis, ocular involvement, aphthous stomatitis, genital ulcers, arthritis, large vessel involvement, or an increase in the erythrocyte sedimentation rate (ESR) or C-reactive protein (CRP). In the inactive group, patients who had responded to therapy and who had achieved remission during the previous month were included.

A group of 40 (18 males and 22 females) age- and gender-matched healthy subjects was used as the negative control group. A positive control group (2 males and 14 females) was also used consisting of patients with systemic lupus erythematosus (SLE) with the idea that SLE is also a vasculitic disorder like BD.

The exclusion criteria for both the patient and control groups were as follows: (i) Those with any metabolic or hormonal abnormality, (ii) Postmenopausal women, (iii) Males older than 50 years of age, (iv) Pregnant women, (v) Nursing women, and (vi) Those taking certain medications such as estrogens, phenothiazines, cimetidine, antidepressants, sulpiride, verapamil, metoclopramide, or opiates.

The following laboratory parameters were studied in all subjects: triiodothyronine (T3), thyroxin $\left(\mathrm{T}_{4}\right)$, the thyroid-stimulating hormone (TSH), the follicle-stimulating hormone (FSH), the luteinizing hormone ( $\mathrm{LH})$, the growth hormone $(\mathrm{GH})$, dihydroepiandrosterone sulphate (DHEAS), estradiol, testosterone, basal cortisol, prolactin (PRL), and the basal adrenocorticotropic hormone (ACTH). Serum samples were obtained in a fasting state at eight o'clock in the morning and were centrifuged to separate the plasma. They were then stored at $-20{ }^{\circ} \mathrm{C}$ in a deep freezer until the analysis. The PRL, FSH, LH, and estradiol levels were obtained between days four and seven of the menstrual cycle of the female patients. The hormone level measurements were performed by using solid phase "chemiluminescent enzyme immunoassay" with the Immulite 2000 Immunoassay System 
(Siemens Healthcare Diagnostics, Tarrytown, NY, USA). Abnormal results were confirmed by testing a second blood specimen.

\section{Statistical analysis}

All results obtained were reported as mean \pm standard deviation (SD) or median (minimum-maximum). The Kruskal-Wallis oneway analysis of variance (ANOVA) was used to compare the hormone levels in the four groups. If a $p$ value of $<0.05$ was obtained, the Mann-Whitney $\mathrm{U}$ test was performed in order to find the source of the difference between the groups. The differences in the ages and disease durations were assessed with Student's t-test, and the differences in gender distributions were analyzed with chi-square tests. The Statistical Package for Social Sciences (SPSS) version 11.0 software program (SPSS Inc., Chicago, Illinois, USA) was used for all statistical analyses.

\section{RESULTS}

\section{Patient characteristics}

The demographic properties of the groups are shown in Table 1. There were no statistically significant differences between the BD, SLE, and healthy groups regarding age and disease duration $(p>0.05)$. No difference was found between the patients with $\mathrm{BD}$ and the healthy group with regard to gender except that patients with SLE were predominantly female ( 2 males versus 14 females, $p<0.05$ ). The patients with $\mathrm{BD}$ had a mean age of $34.4 \pm 9.6$ years (range 18 to 51 years) and a mean disease duration of $7.1 \pm 5.4$ years (range 1 to 20 years).

Oral aphthous ulcers were seen in 40 (93\%) of the 43 Behçet's patients during the clinical course and were the initial symptom of the disease in 35 patients (87.5\%). Twenty-four (55.8\%) had cutaneous lesions which mainly presented as pseudofolliculitis or papulopustular lesions, erythema nodosum-like lesions, or ulcers. Thirty-one $(72 \%)$ had a positive skin pathergy test. Nineteen patients (44.1\%) were found to have genital ulcers, which were the initial manifestation of five of the BD patients (11.6\%). Twenty-one (48.8\%) had ocular lesions, including relapsing anterior and posterior uveitis such as optic neuritis, vitritis, retinal vasculitis, scleritis, keratitis conjunctivitis, iridocyclitis, and hypopyon. Joint involvement occurred in 18 patients (41.8\%) and mainly manifested as monoarthritis, especially in the lower extremities. Sixteen patients (37.2\%) were found to have vascular lesions which commonly presented as superficial thrombophlebitis, but intraabdominal venous thrombosis and arterial occlusions were also seen. Four patients (9.3\%) were found with neurological involvement, such as personality changes, involuntary movements, sphincter disturbances, ataxia, unstable walking, and trouble speaking.

At the time of evaluation, the 43 patients with BD manifested the following: 14 (32.5\%) had ocular involvement ( 8 with anterior uveitis; 5 with posterior uveitis; 1 with retinal vasculitis), 10 (23.2\%) had recurrent oral apthous ulcers, seven (16.2\%) had skin lesions (5 with pseudofolliculitis; 2 with erythema nodosum), seven (16.2\%) had vascular involvement, four $(9.3 \%)$ had central nervous system involvement, three (6.9\%) had genital ulcers, and three (6.9\%) had arthralgia. Thus there were a total 48 active signs for the 43 patients.

\section{Hormone levels}

The follicle-stimulating hormone, $\mathrm{LH}$, prolactin, and DHEAS measurements were evaluated separately in the male and female patients, and the

Table 1. The demographic data of the groups

\begin{tabular}{|c|c|c|c|c|c|c|c|c|c|c|c|c|}
\hline & \multicolumn{2}{|c|}{$\begin{array}{c}\text { Group } 1 \\
\text { (Active BD) }\end{array}$} & \multicolumn{2}{|c|}{$\begin{array}{c}\text { Group } 2 \\
\text { (Inactive } \mathrm{BD} \text { ) }\end{array}$} & \multicolumn{2}{|c|}{$\begin{array}{c}\text { Group } 3 \\
\text { (Ocular } \\
\text { involvement) }\end{array}$} & \multicolumn{2}{|c|}{$\begin{array}{c}\text { Group } 4 \\
\text { (Without ocular } \\
\text { involvement) }\end{array}$} & \multicolumn{2}{|c|}{$\begin{array}{l}\text { Control group } \\
\text { (SLE) }\end{array}$} & \multicolumn{2}{|c|}{$\begin{array}{l}\text { Control group } \\
\text { (Healthy) }\end{array}$} \\
\hline & $\mathrm{n}$ & Mean \pm SD & $\mathrm{n}$ & Mean \pm SD & $\mathrm{n}$ & Mean \pm SD & $\mathrm{n}$ & Mean \pm SD & $\mathrm{n}$ & Mean \pm SD & $\mathrm{n}$ & Mean \pm SD \\
\hline Age (years) & & $35.1 \pm 9.5$ & & $33.6 \pm 8.7$ & & $30.8 \pm 9.4$ & & $36.5 \pm 9.2$ & & $36.0 \pm 10.3$ & & $36.4 \pm 9.8$ \\
\hline \multicolumn{13}{|l|}{ Gender } \\
\hline Male & 15 & & 7 & & 8 & & 14 & & 2 & & 18 & \\
\hline Female & 12 & & 9 & & 6 & & 15 & & 14 & & 22 & \\
\hline $\begin{array}{l}\text { Disease duration } \\
\text { (years) }\end{array}$ & & $8.3 \pm 5.5$ & & $5.0 \pm 4.8$ & & $7.4 \pm 4.5$ & & $7.1 \pm 5.6$ & & $4.6 \pm 3.0$ & & - \\
\hline
\end{tabular}




\begin{tabular}{|c|c|c|c|c|c|c|c|c|}
\hline & \multirow[b]{2}{*}{ Gender } & \multicolumn{2}{|c|}{ Patients with BD group 1} & \multicolumn{2}{|c|}{ SLE control group 2} & \multicolumn{2}{|c|}{ Healthy control group 3} & \multirow[b]{2}{*}{$p$} \\
\hline & & Median & Min.-max. & Median & Min.-max. & Median & Min.-max. & \\
\hline $\mathrm{T} 33(\mathrm{ng} / \mathrm{mL})$ & & 1.11 & $0.70-1.84$ & 0.91 & $0.13-1.40$ & 0.93 & $0.65-1.40$ & $\begin{array}{c}\mathrm{I}-\mathrm{II}=0.006 \\
\mathrm{I}-\mathrm{III}=0.0002\end{array}$ \\
\hline $\mathrm{T}_{4}(\mu \mathrm{g} / \mathrm{dL})$ & & 8.92 & $3.57-11.80$ & 8.15 & $5.0-13.50$ & 9.23 & $6.50-13.40$ & $>0.05$ \\
\hline $\mathrm{TSH}(\mu \mathrm{IU} / \mathrm{mL})$ & & 1.24 & $0.01-5.07$ & 1.02 & $0.11-4.65$ & 1.03 & $0.13-2.57$ & $>0.05$ \\
\hline $\mathrm{FSH}(\mathrm{mIU} / \mathrm{mL})$ & $\begin{array}{l}\mathrm{F} \\
\mathrm{M}\end{array}$ & $\begin{array}{l}4.07 \\
3.30\end{array}$ & $\begin{array}{l}1.70-22 \\
0.17-29.7\end{array}$ & 20.19 & $0.57-28.79$ & $\begin{array}{l}8.25 \\
6.24\end{array}$ & $\begin{array}{l}3.60-24.50 \\
3.06-10.34\end{array}$ & $\begin{array}{c}F: I-I I=0.006 \\
I-I I I=0.002 \\
M: I-I I I=0.002\end{array}$ \\
\hline $\mathrm{LH}(\mathrm{mIU} / \mathrm{mL})$ & $\begin{array}{l}\mathrm{F} \\
\mathrm{M}\end{array}$ & $\begin{array}{l}4.77 \\
4.0\end{array}$ & $\begin{array}{l}1.43-11.30 \\
1.43-20.60\end{array}$ & 11.15 & $0.17-12.60$ & $\begin{array}{l}4.93 \\
4.26\end{array}$ & $\begin{array}{l}2.46-10.40 \\
2.45-25.40\end{array}$ & $>0.05$ \\
\hline Prolactin $(\mathrm{ng} / \mathrm{mL})$ & $\mathrm{F}$ & $\begin{array}{r}10.30 \\
8.02\end{array}$ & $\begin{array}{l}4.06-44.70 \\
2.80-57.70\end{array}$ & 12.30 & $2.69-63.90$ & $\begin{array}{r}10.40 \\
8.17\end{array}$ & $\begin{array}{l}5.12-29.90 \\
4.22-18.10\end{array}$ & $>0.05$ \\
\hline $\mathrm{GH}(\mathrm{ng} / \mathrm{mL})$ & & 0.56 & $0.04-5.2$ & 1.19 & $0.27-5.40$ & 0.62 & $0.04-6.50$ & $\begin{array}{c}\mathrm{I}-\mathrm{II}=0.01 \\
\mathrm{II}-\mathrm{III}=0.004\end{array}$ \\
\hline DHEAS $(\mu \mathrm{g} / \mathrm{dL})$ & $\begin{array}{l}\mathrm{F} \\
\mathrm{M}\end{array}$ & $\begin{array}{r}67.40 \\
107.50\end{array}$ & $\begin{array}{r}4.05-181 \\
23-346\end{array}$ & 35.80 & $18-59.10$ & $\begin{array}{l}101.15 \\
118.70\end{array}$ & $\begin{array}{r}23-217 \\
37.89-229\end{array}$ & $\begin{array}{l}\mathrm{F}: \mathrm{I}-\mathrm{II}=0.008 \\
\mathrm{II}-\mathrm{III}=0.001\end{array}$ \\
\hline Testosterone (pg/mL) & L) $\mathrm{M}$ & 6.30 & $2.24-9.40$ & & & 4.33 & $2.20-5.53$ & $\mathrm{I}-\mathrm{III}=0.0009$ \\
\hline Estradiol (pg/mL) & $\mathrm{F}$ & 69.05 & $18-329$ & 29.95 & $12-213$ & 60.20 & 9-305 & $>0.05$ \\
\hline Cortisol ( $\mu \mathrm{g} / \mathrm{dL})$ & & 14.60 & $0.61-30.53$ & 10.30 & $3.83-35.20$ & 17.28 & $5.42-39.90$ & $\mathrm{II}-\mathrm{III}=0.001$ \\
\hline $\mathrm{ACTH}(\mathrm{pg} / \mathrm{mL})$ & & 27.90 & $3-63$ & 25.30 & $7-138$ & 26.66 & $6.90-248$ & $>0.05$ \\
\hline
\end{tabular}

BD: Behçet's disease; SLE: Systemic lupus erythematosus; Min.: Minimum; Max.: Maximum; TSH: Thyroid stimulating hormone; FSH: Follicle-stimulating hormone; LH: Luteinizing hormone; GH: Growth hormone; DHEAS: Dihydroepiandrosteron sulphate; ACTH: Adrenocorticotropic hormone.

SLE patient levels of these hormones were studied only in females. Triiodothyronin, T4, TSH, basal cortisol, basal ACTH, and GH were studied in all patients, but estradiol was studied only in females and testosterone only in males. The hormone levels of $\mathrm{BD}, \mathrm{SLE}$, and the healthy groups are presented in Table 2.

No significant differences were found between the $\mathrm{BD}, \mathrm{SLE}$, and the healthy control groups regarding the T4, TSH, LH, PRL, estradiol, and ACTH levels (Table 2).

The $\mathrm{T}_{3}$ levels were significantly higher in the $\mathrm{BD}$ patients than in the healthy and SLE controls. The FSH levels were lower in the female BD patients than the female healthy and SLE controls, and they were lower in the male BD patients than in the healthy males. The basal cortisol levels were lower in the SLE patients when compared with both the male and female healthy subjects. The testosterone levels were higher in the male BD patients than in the healthy males, and the GH levels were higher in the SLE patients than in the BD patients and healthy group. The DHEAS levels were lower in the female SLE patients than in the other groups, but the median values of these hormones were all within normal limits of laboratory standards (Table 2).

The hormone levels of the four subgroups of $\mathrm{BD}$ are shown in Table 3. The subgroups of BD did not differ for the $\mathrm{T}_{3}, \mathrm{~T}_{4}, \mathrm{TSH}, \mathrm{FSH}, \mathrm{LH}$, testosterone, estradiol, basal cortisol, or ACTH levels. When comparing prolactinemia, $\mathrm{GH}$, and DHEAS in the BD patients, the median values for PRL and GH were significantly higher in both the male and female patients with ocular involvement. The DHEAS levels were significantly lower in the female patients with ocular involvement (Table 3).

\section{DISCUSSION}

Behçet's disease is a chronic multisystem disorder with vasculitis. It has multiple systemic associations, including involvement of the gastrointestinal, cardiovascular, pulmonary, skeletal, and central nervous systems. ${ }^{[8]}$ However, there have been only a few published reports on the endocrinological involvement of this disease. On the other hand, it has also been suggested that autoimmune diseases develop when endocrine changes caused by various stresses together with some regulatory defects affect autoreactive cells and exceed the 


\begin{tabular}{|c|c|c|c|c|c|c|c|c|c|c|}
\hline & \multirow[b]{2}{*}{ Gender } & \multicolumn{2}{|c|}{$\begin{array}{l}\text { Patients with } \\
\text { active BD } \\
\text { Group 1 }\end{array}$} & \multicolumn{2}{|c|}{$\begin{array}{l}\text { Patients with } \\
\text { inactive BD } \\
\text { Group 2 }\end{array}$} & \multicolumn{2}{|c|}{$\begin{array}{c}\text { Patients with } \\
\text { ocular involvement } \\
\text { Group } 3 \\
\end{array}$} & \multicolumn{2}{|c|}{$\begin{array}{c}\text { Patients without } \\
\text { ocular involvement } \\
\text { Group } 4 \\
\end{array}$} & \multirow[b]{2}{*}{$p$} \\
\hline & & Median & Min.-max. & Median & Min.-max. & Median & Min.-max. & Median & Min.-max. & \\
\hline $\mathrm{T}_{3}(\mathrm{ng} / \mathrm{mL})$ & & 1.13 & $0.78-1.80$ & 1.30 & $0.70-1.84$ & 1.03 & $0.86-1.43$ & 1.27 & $0.8-1.84$ & $>0.05$ \\
\hline $\mathrm{T}_{4}(\mu \mathrm{g} / \mathrm{dL})$ & & 9.29 & $6.65-11.80$ & 7.79 & $3.57-10.70$ & 8.95 & $6.65-10.37$ & 8.71 & $3.5-10.6$ & $>0.05$ \\
\hline $\mathrm{TSH}(\mu \mathrm{IU} / \mathrm{mL})$ & & 1.12 & $0.18-5.07$ & 1.31 & $0.01-2.94$ & 1.03 & $0.66-5.07$ & 1.26 & $0.01-4.9$ & $>0.05$ \\
\hline \multirow{2}{*}{ FSH (mIU/mL) } & $\mathrm{F}$ & 5.31 & $1.7-10.9$ & 4.02 & $2.13-22$ & 3.73 & $1.7-8.5$ & 5.45 & $1.7-11$ & $>0.05$ \\
\hline & M & 3.32 & $0.17-29.7$ & 3.60 & $1.97-8.70$ & 2.75 & $0.17-14.4$ & 3.75 & $0.17-24.6$ & \\
\hline \multirow[t]{2}{*}{ Prolactin $(\mathrm{ng} / \mathrm{mL})$} & F & 11.69 & $6.92-17.7$ & 9.40 & $4.06-44.70$ & 15.50 & $14.5-17.7$ & 8.64 & $5.4-16.7$ & F:I-III $=0.004$ \\
\hline & M & 13.72 & $2.8-57.7$ & 7.14 & $3.60-12.05$ & 19.60 & $6.91-34.4$ & 7.49 & $4.5-13.06$ & $\begin{aligned} \text { II-III } & =0.004 \\
\text { III-IV } & =0.004 \\
\text { M:I-III } & =0.01 \\
\text { II-III } & =0.01 \\
\text { III-IV } & =0.01\end{aligned}$ \\
\hline \multirow[t]{2}{*}{$\mathrm{LH}(\mathrm{mIU} / \mathrm{mL})$} & $\mathrm{F}$ & 5.34 & $1.79-11.3$ & 6.26 & $1.43-10.60$ & 4.03 & $1.79-10.9$ & 6.46 & $1.4-11.3$ & \\
\hline & M & 4.36 & $1.43-8.64$ & 3.95 & $2.28-20.60$ & 3.80 & $2.67-8.64$ & 4.43 & $2.2-17.6$ & $>0.05$ \\
\hline $\mathrm{GH}(\mathrm{ng} / \mathrm{mL})$ & & 1.48 & $0.06-52$ & 0.26 & $0.04-5.80$ & 2.25 & $0.16-52$ & 1.18 & $0.09-6.5$ & II-III $=0.007$ \\
\hline \multirow[t]{2}{*}{ DHEAS ( $\mu \mathrm{g} / \mathrm{dL})$} & $\mathrm{F}$ & 77.05 & 23-152 & 104.0 & $4.05-181$ & 33.05 & $23-43.70$ & 112.5 & $3.75-170$ & F:I-III $=0.006$ \\
\hline & M & 91.7 & $23-346$ & 118 & $62.4-249$ & 72.40 & $28-123$ & 114 & $23-240$ & $\begin{array}{r}\text { II-III }=0.006 \\
\text { III-IV }=0.006\end{array}$ \\
\hline Testosterone $(\mathrm{pg} / \mathrm{mL})$ & M & 5.90 & $2.24-8.10$ & 6.80 & $4.50-9.40$ & 5.09 & $2.24-6.80$ & 6.65 & $4.3-8.9$ & $>0.05$ \\
\hline Estradiol (pg/mL) & $\mathrm{F}$ & 108.70 & $18-329$ & 63.10 & $27.3-90.6$ & 228.50 & $18-329$ & 64.9 & $26-98.7$ & $>0.05$ \\
\hline Basal cortisol $(\mu \mathrm{g} / \mathrm{dL})$ & & 13.86 & $0.61-27.54$ & 13.10 & $7.70-30.53$ & 14.99 & $0.61-27.35$ & 13.11 & $6.5-27.65$ & $>0.05$ \\
\hline Basal ACTH (pg/mL) & & 29.70 & $3-64.31$ & 22.35 & $7-48.40$ & 33.98 & $7-63$ & 24.52 & $6.5-52.4$ & $>0.05$ \\
\hline
\end{tabular}

BD: Behçet's disease; Min.: Minimum; Max.: Maximum; TSH: Thyroid stimulating hormone; FSH: Follicle-stimulating hormone; LH: Luteinizing hormone; GH: Growth hormone; DHEAS: Dihydroepiandrosteron sulphate; ACTH: Adrenocorticotropic hormone.

critical threshold, leading to autoimmunity. ${ }^{[9]}$ In this study, an examination of the basal serum levels of the hypophysial, thyroidal, adrenal, and gonadal hormones in the patients with $\mathrm{BD}$ and the healthy control group showed no clinically significant differences. When the correlation of the hormonal values with disease activity was evaluated, the $\mathrm{BD}$ patients with ocular involvement showed higher PRL and higher $\mathrm{GH}$ values in both genders and lower DHEAS levels in the female patients.

The rate of the presence of diseases with autoimmune events in their pathogenesis is high. Primary adrenal failure, which is an autoimmune disease, may accompany BD for the etiopathogenesis for which autoimmunity is held responsible. ${ }^{[6]}$ Studies which have evaluated the basal adrenal functions in BD patients found no decrease. ${ }^{[6,10]}$ Colak et al. ${ }^{[6]}$ found that cortisol values in the $60^{\text {th }}$ minute in a 1 mcg low-dose ACTH stimulation test (LDT) were significantly lower in the $\mathrm{BD}$ group than in the control group. In the peak cortisol responses to the LDT, a significant decrease was found in the BD patients, so it was concluded that the hypothalamopituitary-adrenal axis was partially suppressed with BD. In our study, an examination of the basal cortisol and ACTH values in the BD patient group and healthy control group showed no statistically significant differences. Interestingly, the cortisol levels in the SLE patients were found to be lower than the healthy control group but did not differ from the BD group.

Increasing evidence indicates that prolactin has an immunomodulatory influence on the immune system. ${ }^{[1]}$ In some studies, it has been suggested that there is a correlation between high serum prolactin levels and BD activity. ${ }^{[5,12]}$ The elevated levels of prolactin may contribute to disease activity by augmenting immune processes. Proença et al. ${ }^{[12]}$ suggested that prolactin can play a role in $\mathrm{BD}$ pathogenesis and disease expression, especially in complete-type BD.

In the present study, a comparison of the PRL levels between the patient and control groups revealed no significant difference. Among the $\mathrm{BD}$ subgroups, the median prolactinemia difference was statistically significant in the BD patients with ocular involvement, but we found no statistically significant difference in prolactin levels between inactive and active BD. It may be suggested that abnormal PRL levels are more strongly correlated in the most severe cases, which may explain why some authors have reported no relationship between disease activity and PRL 
levels. ${ }^{[13,14]}$ Differences in study designs and patient selection may explain the contradictory results in the literature. Moreover, environmental or genetic factors may also play a role. More comprehensive studies are needed to clarify the possible clinical significance of hyperprolactinemia in a subset of patients with BD.

Aksu et al..$^{[15]}$ and Akdeniz et al. ${ }^{[16]}$ reported that thyroid functions were normal in patients with BD. However, pituitary gland response to TRH stimulation was found to decrease. ${ }^{[16]}$ In our study, the T4 and TSH levels were not significantly different between the BD, SLE, and healthy control groups. The $\mathrm{T}_{3}$ levels were higher in the $\mathrm{BD}$ patients than the other groups, but the median $\mathrm{T}_{3}$ levels were within normal ranges in all groups. Therefore, this high level was not found to be clinically significant.

We could not find a study assessing gonadal functions in BD patients. In our study, we found that the FSH levels were lower in the male and female BD patients compared with their healthy counterparts. No statistically significant differences were found regarding the estradiol levels between the $\mathrm{BD}$ and control groups. The testosterone levels were higher in the male $\mathrm{BD}$ patients than in the healthy males. These differences in hormone levels were not found to be clinically relevant since the median values of these hormones were all within the normal limits of laboratory standards.

The GH and DHEAS levels were not statistically different between the $\mathrm{BD}$ and healthy control groups, but the GH levels were higher in the SLE patients, and the DHEAS levels were lower in the female SLE patients when compared with the BD patients and the healthy group. The female BD patients having ocular involvement had lower levels of DHEAS compared with the active BD and the group without ocular involvement. The GH levels were significantly higher in both the male and female patients with ocular involvement. Since no study exists which has assessed DHEAS and GH in $\mathrm{BD}$ patients, the relevance and significance of these findings are obscure.

Eventually, we concluded that despite being a disease that is associated with vasculitis, BD has no major influence on the endocrine system. Further, more detailed studies with larger BD study groups are needed to evaluate the importance and extent to which
PRL, GH, and DHEAS values correlate with ocular involvement.

\section{Declaration of conflicting interests}

The authors declared no conflicts of interest with respect to the authorship and/or publication of this article.

\section{Funding}

The authors received no financial support for the research and/or authorship of this article.

\section{REFERENCES}

1. Sakane T, Takeno M, Suzuki N, Inaba G. Behçet's disease. N Engl J Med 1999;341:1284-91.

2. Emmi L, Brugnolo F, Salvati G, Marchione $T$. Immunopathological aspects of Behçet's disease. Clin Exp Rheumatol 1995;13:687-91.

3. Kastner DL. Behçet's disease. In: Koopman WJ, editor. Arthitis and allied conditions. A textbook of rheumatology. 14th ed. Philadelphia: Lippincott Williams Willkins; 2001. p. 1420-29.

4. Walker SE, Jacobson JD. Roles of prolactin and gonadotropin-releasing hormone in rheumatic diseases. Rheum Dis Clin North Am 2000;26:713-36.

5. Atasoy M, Karatay S, Yildirim K, Kadi M, Erdem T, Senel $\mathrm{K}$. The relationship between serum prolactin levels and disease activity in patients with Behcet's disease. Cell Biochem Funct 2006;24:353-6.

6. ColakR, Ozkan Y, Cengiz SU, SaralY, Kandi BC, Halifeoglu I. A comparison between the effects of low $(1 \mathrm{microg})$ and standard dose (250 microg) ACTH stimulation tests on adrenal cortex functions with Behçet's disease. J Eur Acad Dermatol Venereol 2006;20:721-5.

7. Criteria for diagnosis of Behçet's disease. International Study Group for Behçet's Disease. Lancet 1990;335:1078-80.

8. Onder M, Gürer MA. The multiple faces of Behçet's disease and its aetiological factors. J Eur Acad Dermatol Venereol 2001;15:126-36.

9. Chrousos GP, Elenkov IJ. Interactions of the endocrine and immune systems. In: De Groot LJ, Jameson JL, editors. Endocrinology. 4th ed. Philadelphia: Saunders; 2001. p. 571-86.

10. Ohguchi M. Endocrinological examinations in Behçet's disease (author's transl). Nihon Ganka Gakkai Zasshi 1979;83:1486-93. [Abstract]

11. Buskila D, Sukenik S, Shoenfeld Y. The possible role of prolactin in autoimmunity. Am J Reprod Immunol 1991;26:118-23.

12. Proença H, Ferreira C, Miranda M, Castanheira-Dinis A, Monteiro-Grillo M. Serum prolactin levels and Behçet disease. Eur J Ophthalmol 2007;17:404-7. 
13. Houman H, Ben Ghorbel I, Lamloum M, Feki M, Khanfir M, Mebazaa A, et al. Prolactin levels in Behçet's disease: no correlation with disease manifestations and activity. Ann Med Interne (Paris) 2001;152:209-11.

14. Keser G, Oksel F, Ozgen G, Aksu K, Doganavsargil E. Serum prolactin levels in Behçet's Syndrome. Clin Rheumatol 1999;18:351-2.
15. Aksu K, Oksel F, Keser G, Ozgen AG, Ynal V, Kabalak $\mathrm{T}$, et al. Thyroid functions in Behçet's disease. Clin Endocrinol (Oxf) 1999;50:406-7.

16. Akdeniz S, Colak S, Tuzcu AK, Bahceci M, Harman M. Baseline and stimulated thyroid functions in Behçet's disease. J Eur Acad Dermatol Venereol 2006; 20:878-9. 